E-JURNAL EKONOMI DAN BISNIS UNIVERSITAS UDAYANA
Available online at https://ojs.unud.ac.id/index.php/EEB/index
Vol. 10 No. 09, September 2021, pages: 799-808
e-ISSN: 2337-3067

\title{
PENGARUH STRUKTUR PENGENDALIAN INTERNAL TERHADAP KREDIT BERMASALAH PADA BANK BRI DI DENPASAR
}

\section{Ni Putu Via Rista ${ }^{1}$ Ni Luh Sari Widhiyani ${ }^{2}$}

\begin{tabular}{l}
\hline \multicolumn{1}{c}{ Article history: } \\
\hline Submitted: 11 Juni 2021 \\
Revised: 25 Juni 2021 \\
Accepted: 8 Juli 2021 \\
\hline
\end{tabular}

\section{Keywords:}

Control Environment;

Risk Assessment;

Control Activities;

Information and

Communication;

Monitoring;

\section{Kata Kunci:}

Lingkungan Pengendalian;

Penilaia Resiko;

Aktivitas Pengendalian; Informasi dan Komunikasi; Pemantauan;

\section{Koresponding:}

Fakulas Ekonomi dan Bisnis Universitas Udayana, Bali, Indonesia

Email:viarista25@gmail.com

\begin{abstract}
This study aims to obtain empirical evidence of the effect of internal control on non-performing loans at Bank BRI in Denpasar. The population in this study were all employees of the Denpasar branch of BRI bank. The number of BRI banks in Denpasar is 18 banks. The sample in this study were several employees at each BRI bank in Denpasar Branch. The number of samples obtained consists of 64 respondents using a non-probability sampling method, namely purposive sampling technique. Data was collected by using the questionnaire method. The data analysis technique used is multiple linear regression analysis. Based on the results of this study, it shows that the internal control structure has a significant negative effect on non-performing loans at Bank BRI in Denpasar. The implication of this research is that it can contribute to the application of agency theory and behavioral theory and can provide input to banks to carry out better internal control to minimize non-performing loans.
\end{abstract}

Abstrak
Penelitian ini bertujuan untuk mendapatkan bukti empiris pengaruh
pengendalian internal terhadap kredit bermasalah pada Bank BRI di
Denpasar. Populasi dalam penelitian ini yaitu seluruh karyawan bank BRI
Cabang Denpasar. Jumlah bank BRI di Denpasar yaitu 18 bank. Sampel
penelitian ini yaitu beberapa karyawan pada masing- masing bank BRI di
Cabang Denpasar. Jumlah sampel yang diperoleh yaitu terdiri dari 64
responden dengan menggunakan metode non-probability sampling yaitu
teknik purposive sampling. Pengumpulan data dilakukan dengan metode
kuesioner. Teknik analisis data yang dilakukan adalah analisis regresi linier
berganda. Berdasarkan hasil penelitian ini menunjukkan struktur
pengendalian internal berpengaruh negatif signifikan terhadap kredit
bermasalah pada Bank BRI di Denpasar. Implikasi dalam penelitian ini yaitu
dapat memberikan kontribusi pada pengaplikasian theory agency dan teori
keprilakuan serta dapat memberikan masukan kepada pihak bank agar
melakukan pengendalian internal yang lebih baik untuk meminimalisir
kredit bermasalah.

Fakultas Ekonomi dan Bisnis Universitas Udayana, Bali, Indonesia ${ }^{2}$

Email: sariwidhiyani@unud.ac.id 


\section{PENDAHULUAN}

Lembaga keuangan memiliki peranan penting dalam perekonomian, sebagai wadah yang menghimpun dan menyalurkan dana masyarakat secara efektif dan efisien untuk mencapai kesejahteraan masyarakat. Menurut Undang-Undang Nomor 10 Tahun 1998 Perbankan adalah badan usaha yang menghimpun dana dari masyarakat dalam bentuk simpanan dan menyalurkannya kepada masyarakat dalam bentuk kredit dan/atau bentuk lainnya dalam rangka meningkatkan taraf hidup masyarakat. pada umumnya. Sebagai badan usaha, bank berupaya untuk memperoleh keuntungan yang sebesar-besarnya. Profitabilitas bagi bank sangat berarti dalam upaya mempertahankan keberadaan bank tersebut dalam jangka panjang, karena laba memperlihatkan apakah perusahaan memiliki prospek yang baik di masa mendatang (Hidayat, 2016).

Menurut Ghazwani (2016), penyebab utama kegagalan bank adalah adanya kredit bermasalah (NPL). Kredit diklasifikasikan sebagai kredit bermasalah jika tergolong kurang lancar, diragukan atau macet (Karuniawati, 2017). Adanya kredit bermasalah dapat menurunkan laba operasional bank yaitu dari bunga yang seharusnya diperoleh. Kredit bermasalah merupakan salah satu bentuk risiko yang harus diselesaikan baik oleh lembaga keuangan maupun lembaga keuangan non bank (Afkar, 2018). Rasio kredit bermasalah atau NPL pada bank konvensional di Bali pada tahun 2019 cukup tinggi, mencapai 3,52\%. NPL atau kredit bermasalah perlu diminimalisir agar pertumbuhan ekonomi bisa meningkat. Untuk meminimalisir adanya kredit macet, perlu dilakukan pengendalian internal bank untuk meningkatkan kualitas Sumber Daya Manusia (SDM) guna mengatasi pembiayaan bermasalah. Berdasarkan data Laporan Tahunan 2019, diketahui bank BRI memiliki persentase nilai NPL yang terus meningkat dari tahun ke tahun akibat penurunan kolektibilitas kredit.

Menurut Aryasa \& Wasistha (2018), sistem pengendalian dapat digunakan untuk menilai pelaksanaan pengawasan internal dan kebijakan manajemen bank dalam menjalankan tugasnya. Pengendalian yang digunakan adalah pengendalian inter, yaitu suatu proses yang dilakukan oleh dewan direksi, manajemen, dan personel lainnya dalam suatu entitas, yang dirancang untuk memberikan keyakinan memadai mengenai pencapaian tujuan perusahaan (Rotti et al., 2017). Pengendalian internal yang efisien dapat meminimalisir terjadinya kredit macet dan sebagai dasar kegiatan operasional yang sehat dan aman sehingga dapat dipercaya oleh masyarakat (Ekinci, 2016). Manajemen perlu melakukan tindakan pemantauan untuk mengurangi risiko yang muncul di masa depan untuk mencegah kredit macet yang disebabkan oleh karyawan itu sendiri. Tambahan, bank harus memiliki sistem informasi yang mencakup metode dan catatan untuk menunjukkan dan mencatat semua transaksi peminjaman yang sah. Oleh karena itu, bank perlu melakukan pengendalian internal yang meliputi lingkungan pengendalian, penilaian risiko, aktivitas pengendalian, informasi dan komunikasi, serta aktivitas pemantauan untuk meminimalkan kredit bermasalah.

Lingkungan pengendalian memiliki peran penting dalam menetapkan tujuan, struktur organisasi yang jelas, dan penentuan wewenang dan tanggung jawab setiap orang yang terlibat dalam struktur organisasi. Lingkungan pengendalian dapat tercermin dalam struktur organisasi, semakin baik lingkungan pengendalian yang diterapkan maka semakin rendah kredit bermasalah. Penelitian Rotti et al (2017) menyatakan bahwa lingkungan pengendalian berpengaruh negatif terhadap kredit bermasalah.

Pratama (2017) menyatakan bahwa penilaian risiko adalah identifikasi suatu entitas dan analisis risiko yang relevan untuk mencapai tujuannya, membentuk dasar untuk menentukan 
bagaimana risiko harus dikelola. Setiap organisasi harus mampu menilai risiko yang akan dihadapinya untuk mencegah terjadinya risiko internal perusahaan. Penelitian oleh I Gede Sukadanayasa \&

Aktivitas pengendalian adalah tindakan yang ditetapkan melalui kebijakan dan prosedur yang membantu memastikan bahwa manajemen mengarahkan untuk mengurangi risiko guna mencapai tujuan. Adanya pemisahan tugas yang sesuai dengan fungsi pengendalian dalam suatu organisasi perlu dilakukan agar pengendalian internal dapat berjalan dengan baik. Penelitian Rotti et al (2017) menyatakan bahwa aktivitas pengendalian berpengaruh negatif terhadap kredit bermasalah. Informasi yang dibutuhkan oleh manajemen adalah informasi yang relevan dan berkualitas baik yang berasal dari sumber internal dan eksternal serta digunakan untuk mendukung fungsi komponen pengendalian internal lainnya. Penelitian Rotti et al (2017) menyatakan bahwa informasi dan komunikasi berpengaruh negatif terhadap kredit bermasalah.

Informasi dan komunikasi merupakan pengidentifikasian, penangkapan, dan pertukaran informasi dalam suatu bentuk dan waktu yang memungkinkan orang melaksanakan tanggung jawab mereka (Pratama,2017). Jika perusahaan tidak memiliki informasi dan komunikasi yang baik maka pengendalian internal tidak dapat berjalan dengan baik Penelitian oleh Rotti dkk (2017) menyatakan bahwa informasi dan komunikasi berpengaruh negatif pada kredit bermasalah.

Monitoring adalah kegiatan evaluasi dengan beberapa bentuk yang dilakukan secara terus menerus, terpisah atau gabungan keduanya. Pemantauan meliputi proses penilaian kinerja pengendalian internal dan memastikan apakah semuanya telah dilakukan sesuai keinginan dan apakah telah disesuaikan dengan keadaan yang berubah (Hasbiana \& Aditya, 2021). Jika perusahaan tidak melakukan pengawasan dengan baik maka pengendalian internal tidak dapat berjalan dengan baik. Penelitian Rotti et al (2017) menyatakan bahwa monitoring berpengaruh negatif terhadap kredit bermasalah.

Dalam penelitian ini menggunakan 2 (dua) teori yaitu teori keagenan sebagai teori dasar dan teori atribusi sebagai teori pendukung. Teori keagenan menjelaskan hubungan antara prinsipal dan agen. Hubungan keagenan terjadi dengan melibatkan dua pihak yaitu agen dan prinsipal yang kemudian membuat kesepakatan dalam pendelegasian wewenang untuk melaksanakan suatu jasa (Anthony \& Govindarajan, 2005:269). Dalam hal ini prinsipal adalah pihak yang memberikan amanat sedangkan agen adalah pihak yang diberi amanah. Kredit bermasalah (NPL) erat kaitannya dengan teori keagenan, dimana bank dan debitur menjadi aktor utamanya. Dalam pemberian kredit dapat terjadi benturan kepentingan antara prinsipal (bank) dengan agen (debitur), dimana debitur tidak melaksanakan kewajibannya sesuai dengan perjanjian dengan bank dan hal ini berdampak pada profitabilitas bank. Pada kasus ini, pengelolaan lembaga keuangan perlu dilakukan pengawasan dan pengendalian untuk memastikan pengelolaannya telah dilakukan berdasarkan peraturan perundangundangan yang berlaku (Ari \& Wilatini, 2019). Dengan adanya pengendalian internal yaitu lingkungan pengendalian, aktivitas pengendalian, penilaian risiko, sistem informasi dan komunikasi, serta pemantauan diharapkan dapat menjadi cara yang efektif dan efisien untuk mengurangi jumlah NPL di dunia perbankan.

Teori atribusi menjelaskan bahwa perilaku individu dapat dipengaruhi oleh dua faktor, yaitu faktor internal dan faktor eksternal. Teori atribusi dapat menjelaskan bahwa faktor internal maupun faktor eksternal individu yang dapat memicu terjadinya kredit bermasalah. Faktor internal yang dapat memicu terjadinya kredit bermasalah adalah debitur itu sendiri. Jika debitur memiliki rasa tanggung jawab untuk membayar kreditnya, maka tidak akan terjadi kredit bermasalah. Sedangkan 
faktor eksternal yang dapat memicu terjadinya kredit bermasalah berasal dari lingkungan kerja karyawan itu sendiri. Jika suatu perusahaan memiliki lingkungan yang tidak kondusif, maka bawahan akan cenderung melakukan kecurangan.

Berdasarkan penjelasan rumusan masalah, dan penelitian-penelitian sebelumnya, dapat dirumuskan beberapa hipotesis penelitian sebagai berikut: H1: Lingkungan pengendalian berpengaruh negatif terhadap kredit bermasalah; $\mathrm{H} 2$ : Penilaian risiko berpengaruh negatif terhadap kredit bermasalah; H3: Aktivitas pengendalian berpengaruh negatif terhadap kredit bermasalah; H4: Informasi dan komunikasi berpengaruh negatif terhadap kredit bermasalah; H5: Pemantauan berpengaruh negatif terhadap kredit bermasalah.

\section{METODE PENELITIAN}

Penelitian ini memperlihatkan bagaimana pengaruh lingkungan pengendalian, penilaian risiko, aktivitas pengendalian, informasi dan komunikasi, dan pemantauan terhadap kredit bermasalah pada Bank BRI di Denpasar. Lokasi penelitian dilakukan pada Bank BRI di Denpasar karena Denpasar merupakan pusat kegiatan bisnis di Bali. Jenis data yang digunakan dalam penelitian ini menggunakan data kuantitatif, yang diperoleh melalui jawaban responden dalam kuesioner (data primer) dan yaitu laporan keuangan tahun 2019 bank BUMN (data sekunder). Populasi dalam penelitian ini yaitu seluruh karyawan bank BRI Cabang Denpasar, yang meliputi satu KCP (Kantor Cabang Pembantu) dan 16 Kantor Unit di bawah kantor cabang Denpasar yaitu Kantor Unit Sanur, Kantor Unit Gatot Subroto, Kantor Unit Kreneng, Kantor Unit Penatih, Kantor Unit Sidakarya, Kantor Unit Gerenceng, Kantor Unit monang Maning, Kantor Unit Sesetan, Kantor Unit Melati, Kantor Unit Gunung Agung, Kantor Unit Imambonjol, Kantor Unit Diponogoro, Kantor Unit Teuku Umar, Kantor Unit Tohpati, Kantor Unit Renon, dan Kantor Unit Sudirman serta 1 kantor cabang pembantu yaitu KCP Hayam Wuruk. Sampel penelitian ini yaitu beberapa karyawan pada masing- masing bank BRI di Cabang Denpasar sebagai responden, yang diperoleh dengan metode nonprobability sampling yaitu teknik purposive sampling, sehingga didapatkan 64 responden. Metode pengumpulan data yang digunakan dalam penelitian ini adalah kuesioner, dan untuk mengukur jawaban responden dalam penelitian ini, maka digunakan pengukuran skala Likert. Teknik analisis data dalam penelitian ini adalah Teknik analisis statistic deskriptif dengan uji asumsi klasik yang terdiri dari uji normalitas, uji multikolinearitas dan uji heteroskedastisitas, kemudian menguji dengan uji regresi linear berganda, uji koefesien determinasi, uji kelayakan model, dan melakukan uji hipotesis.

\section{HASIL DAN PEMBAHASAN}

Karakteristik responden berdasarkan jenis kelamin menunjukkan bahwa jenis kelamin perempuan mendominasi dalam penelitian ini dengan persentase 54,69\%. Berdasarkan usia, responden yang memiliki usia 25-30 tahun mendominasi dengan persentase 45,31\%. Artinya seluruh sampel yang digunakan dalam penelitian ini adalah pegawai Bank BRI di Denpasar yang sudah memiliki pengalaman. Berdasarkan lama bekerja, responden pada Bank BRI di Denpasar yang bekerja selama 6-10 tahun mendominasi dengan persentase sebesar 53,13\%. 
Tabel 1.

Karakteristik Responden

\begin{tabular}{ccccc}
\hline Tidak & Variabel & Klasifikasi & $\begin{array}{c}\text { Jumlah } \\
\text { (orang) }\end{array}$ & $\begin{array}{c}\text { Persentase } \\
(\mathbf{\%})\end{array}$ \\
\hline \multirow{3}{*}{1} & Jenis & Pria & 29 & 45,31 \\
& kelamin & Perempuan & 35 & 54,69 \\
& & Total & 64 & 100,00 \\
2 & Usia & $21-25$ tahun & 5 & 7,81 \\
& & $25-30$ tahun & 29 & 45,31 \\
& & $31-35$ tahun & 20 & 31,25 \\
& & $>35$ tahun & 10 & 15,63 \\
& & Total & 64 & 100,00 \\
& & $1-5$ tahun & 15 & 23.44 \\
& & $6-10$ tahun & 34 & 53,13 \\
& Lama & $11-15$ tahun & 10 & 15,63 \\
& bekerja & $>15$ tahun & 5 & 7,81 \\
& & Total & 64 & 100,00 \\
\hline
\end{tabular}

Sumber : Data diolah, 2021

Tabel 2.

Hasil Analisis Statistik Deskriptif

\begin{tabular}{lccccc}
\hline Variabel & N & Minimum & Maksimum & Berarti & Std. Deviasi \\
\hline Lingkungan Pengendalian (X1) & 64 & 2.000 & 4,000 & 3,429 & 0,535 \\
Penilaian Risiko (X2) & 64 & 2.000 & 4,000 & 3,453 & 0,532 \\
Aktivitas Pengendalian (X3) & 64 & 2.000 & 4,000 & 3.296 & 0,554 \\
Informasi dan Komunikasi (X4) & 64 & 2.000 & 4,000 & 3.367 & 0,643 \\
Pemantauan (X5) & 64 & 2.000 & 4,000 & 3,492 & 0,499 \\
Kredit Bermasalah (Y) & 64 & 1,450 & 3,450 & 2,324 & 0,486 \\
\hline
\end{tabular}

Sumber: Data diolah, 2021

Hasil analisis deskriptif pada tabel masing-masing variabel penelitian dapat dideskripsikan sebagai berikut: Variabel lingkungan pengendalian (X1) memiliki nilai minimum 2 dan nilai maksimum 4. Nilai rata-rata lingkungan pengendalian sebesar 3.429, menunjukkan bahwa Bank BRI di Denpasar memiliki lingkungan pengendalian yang baik, dengan standar deviasi 0,535. Variabel penilaian risiko (X2) memiliki nilai minimum 2 dan nilai maksimum 4. Nilai rata-rata penilaian risiko sebesar 3,353 menunjukkan bahwa Bank BRI di Denpasar memiliki penilaian risiko tinggi, dengan standar deviasi 0,523. Variabel aktivitas pengendalian (X3) memiliki nilai minimum 2 dan nilai maksimum 4. Nilai rata-rata aktivitas pengendalian sebesar 3,296, menunjukkan bahwa Bank BRI di Denpasar memiliki aktivitas pengendalian yang cukup baik, dengan standar deviasi 0,554. Variabel informasi dan komunikasi (X4) memiliki nilai minimum 2 dan nilai maksimum 4. Nilai rata-rata informasi dan komunikasi adalah 3,367, menunjukkan bahwa Bank BRI di Denpasar memiliki informasi dan komunikasi yang cukup baik, dengan standar deviasi 0,643. Variabel pemantauan (X5) memiliki nilai minimum 2 dan nilai maksimum 4. Nilai pemantauan rata-rata 3,492 menunjukkan bahwa Bank BRI di Denpasar memiliki pemantauan yang baik, dengan standar deviasi 0,499 Variabel kredit bermasalah $(\mathrm{Y})$ memiliki nilai minimum 1,450 dan nilai maksimum 3,450. Nilai rata-rata kredit bermasalah sebesar 2,324 menunjukkan bahwa Bank BRI di Denpasar memiliki kredit bermasalah yang rendah, dengan standar deviasi sebesar 0,486. 
Berdasarkan uji normalitas menggunakan One-Sample Kolmogorov-Smirnov Test menunjukkan bahwa besarnya nilai Asymp. Sig. (2-tailed) Kolmogorov-Smirnov adalah 0,081. Nilai Kolmogorov-Smirnov lebih besar dari nilai alpha 0,05 yang menunjukkan bahwa data yang digunakan dalam penelitian ini berdistribusi normal, sehingga dapat disimpulkan model memenuhi asumsi normalitas.

Berdasarkan uji multikolinearitas didapatkan bahwa tidak ada variabel bebas yang memiliki nilai toleransi kurang dari 0,10 dan juga tidak ada variabel bebas yang memiliki nilai VIF lebih dari 10. Oleh karena itu model regresi bebas dari gejala multikolinearitas.

Berdasarkan uji heteroskedastisitas diketahui bahwa masing-masing variabel seperti lingkungan pengendalian $(0,085)$, penilaian risiko $(0,847)$, aktivitas pengendalian $(0,396)$, informasi dan komunikasi $(0,219)$ dan pemantauan $(0,380)$ memiliki nilai signifikansi lebih besar dari $5 \%(0,05)$. Hal ini menunjukkan bahwa variabel bebas yang digunakan dalam penelitian ini tidak berpengaruh signifikan terhadap variabel terikat, sehingga penelitian ini bebas dari gejala heteroskedastisitas.

Tabel 3.

Hasil Analisis Regresi Linear Berganda

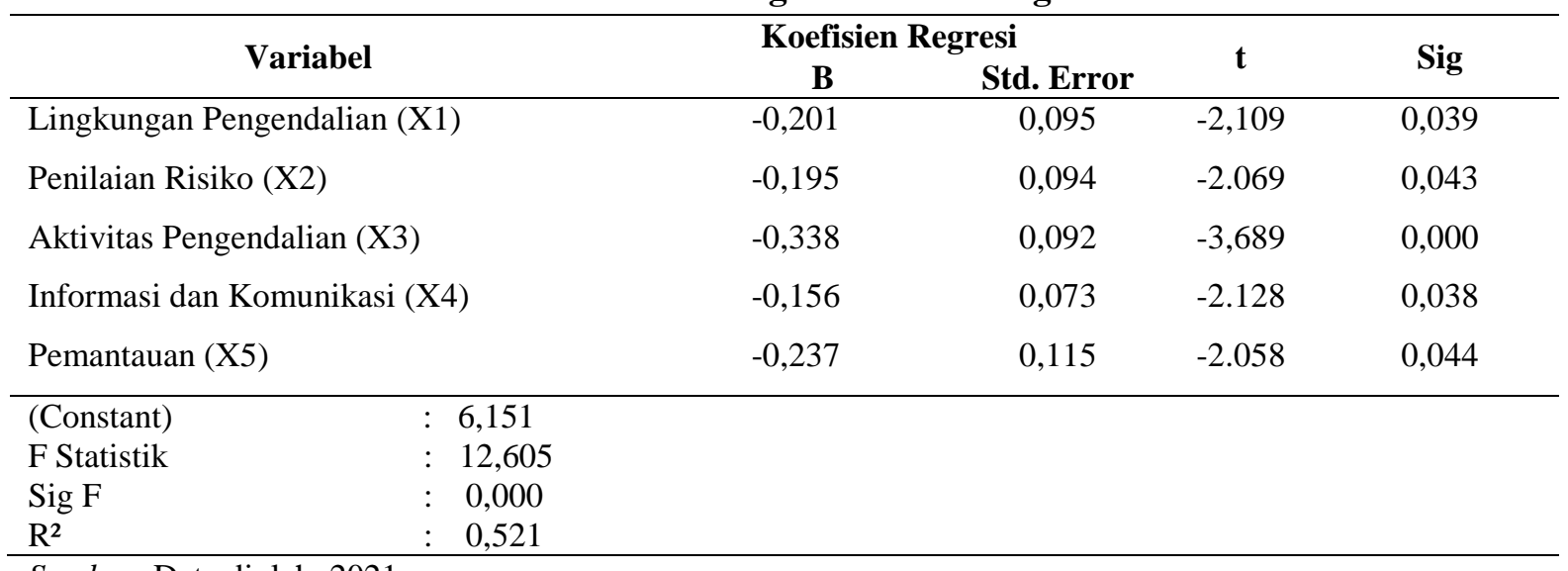

Sumber: Data diolah, 2021

Nilai konstanta sebesar 6,151 menunjukkan bahwa jika lingkungan pengendalian, variabel penilaian risiko, aktivitas pengendalian, informasi dan komunikasi, dan pemantauan sama dengan 0 (nol), maka kredit bermasalah pada Bank BRI di Denpasar adalah sebesar 6,151. Nilai koefisien variabel lingkungan pengendalian sebesar -0,201 menunjukkan bahwa lingkungan pengendalian berpengaruh negatif terhadap kredit bermasalah pada Bank BRI di Denpasar, jika lingkungan pengendalian meningkat maka kredit bermasalah akan menurun. Nilai koefisien variabel penilaian risiko sebesar -0,195 menunjukkan bahwa penilaian risiko berpengaruh negatif terhadap kredit bermasalah pada Bank BRI di Denpasar, jika penilaian risiko meningkat maka kredit bermasalah akan menurun. Nilai koefisien variabel aktivitas pengendalian sebesar -0,338 menunjukkan bahwa aktivitas pengendalian berpengaruh negatif terhadap kredit bermasalah pada Bank BRI di Denpasar, jika aktivitas pengendalian meningkat maka kredit bermasalah akan menurun. Nilai koefisien variabel informasi dan komunikasi sebesar -0,156 menunjukkan bahwa informasi dan komunikasi berpengaruh negatif terhadap kredit bermasalah pada Bank BRI di Denpasar, jika informasi dan komunikasi meningkat maka kredit bermasalah akan menurun. Nilai koefisien variabel pemantauan sebesar -0,237 menunjukkan bahwa monitoring berpengaruh negatif terhadap kredit bermasalah pada Bank BRI di Denpasar, jika monitoring meningkat maka kredit bermasalah akan menurun 
Berdasarkan hasil pengujian diperoleh nilai F-hitung sebesar 12,605 dengan signifikansi 0,000 yang berada dibawah 0,05 sehingga dapat disimpulkan bahwa model regresi fit dengan data observasi sehingga layak digunakan sebagai alat analisis untuk menguji pengaruh variabel bebas terhadap variabel terikat.

Berdasarkan hasil pengujian koefisien determinasi diperoleh nilai $\mathrm{R}^{2}=52,1$ persen yang berarti 52,1 persen kredit bermasalah pada Bank BRI di Denpasar dipengaruhi oleh variabel lingkungan pengendalian (X1), variabel penilaian risiko (X2), variabel pengendalian kegiatan (X3), informasi dan komunikasi (X4), pemantauan (X5) dan sisanya 47,9 persen dipengaruhi oleh variabel lain yang tidak diteliti dalam penelitian ini.

Hasil pengujian hipotesis pertama mengenai pengaruh lingkungan pengendalian terhadap kredit bermasalah menunjukkan nilai signifikansi sebesar 0,039 dengan koefisien regresi negatif sebesar 0,201. Nilai signifikansi 0,039 lebih kecil dari $=0,05$. Berdasarkan hasil pengujian, maka H1 diterima. Artinya terdapat pengaruh negatif dan signifikan antara lingkungan pengendalian terhadap kredit bermasalah pada Bank BRI di Denpasar. Artinya semakin baik gaya operasi dan struktur organisasi perusahaan, maka semakin baik pula lingkungan kerjanya. Lingkungan pengendalian merupakan dasar bagi seluruh komponen pengendalian internal yang membentuk disiplin dan struktur. Lingkungan pengendalian mengarahkan organisasi dan mempengaruhi kesadaran orang-orang dalam organisasi (Halim, 2008:212). Hal ini sejalan dengan teori keagenan yang mencerminkan tanggung jawab seluruh karyawan sesuai dengan struktur organisasi yang telah ditetapkan. Penelitian ini didukung oleh hasil penelitian Dewi dan Widhiyani (2018) yang menyatakan bahwa lingkungan pengendalian berpengaruh negatif signifikan terhadap kecenderungan kredit macet. Semakin baik lingkungan pengendalian di perbankan maka kecenderungan kredit macet akan semakin berkurang.

Hasil pengujian hipotesis kedua mengenai pengaruh penilaian risiko terhadap kredit bermasalah menunjukkan nilai signifikansi sebesar 0,043 dengan koefisien regresi negatif sebesar 0,195. Nilai signifikansi 0,043 lebih kecil dari $=0,05$. Berdasarkan hasil pengujian, maka H2 diterima. Artinya terdapat pengaruh negatif dan signifikan antara penilaian risiko kredit bermasalah pada Bank BRI di Denpasar. Artinya penyusunan laporan keuangan yang baik akan mengurangi risiko internal perusahaan. Menciptakan tanggung jawab karyawan yang baik. Setiap organisasi harus mampu menilai risiko yang akan dihadapinya. Penilaian risiko bank dapat tercermin dari penerapan pengendalian intern dalam pemberian kredit bank, dimana selalu dilakukan analisis terhadap kemampuan debitur untuk membayar kembali kreditnya. Sejalan dengan teori keagenan, yang tetap memperhatikan keuntungan antara bank dan debitur sesuai dengan kesepakatan yang telah disepakati. Semakin tinggi penilaian risiko yang dilakukan oleh bank, semakin rendah NPL atau kredit bermasalah. Penelitian ini didukung oleh hasil penelitian Dewi dan Widhiyani (2018) yang menyatakan bahwa penilaian risiko berpengaruh negatif signifikan terhadap kecenderungan kredit macet. Semakin baik penilaian risiko di bank, maka kecenderungan kredit macet akan semakin berkurang. Penelitian ini didukung oleh hasil penelitian Dewi dan Widhiyani (2018) yang menyatakan bahwa penilaian risiko berpengaruh negatif signifikan terhadap kecenderungan kredit macet. Semakin baik penilaian risiko di bank, maka kecenderungan kredit macet akan semakin berkurang. Penelitian ini didukung oleh hasil penelitian Dewi dan Widhiyani (2018) yang menyatakan bahwa penilaian risiko berpengaruh negatif signifikan terhadap kecenderungan kredit macet. Semakin baik penilaian risiko di bank, maka kecenderungan kredit macet akan semakin berkurang.

Hasil pengujian hipotesis ketiga mengenai pengaruh aktivitas pengendalian terhadap kredit bermasalah menunjukkan nilai signifikansi sebesar 0,000 dengan nilai koefisien regresi negatif sebesar 0,338. Nilai signifikansi 0,000 lebih kecil dari = 0,05. Berdasarkan hasil pengujian, maka H3 diterima. 
Artinya terdapat pengaruh negatif dan signifikan antara aktivitas pengendalian terhadap kredit bermasalah pada Bank BRI di Denpasar. Artinya pemisahan fungsi yang jelas akan menciptakan tanggung jawab pegawai yang baik. Pengendalian intern merupakan kebijakan dan prosedur yang secara langsung atau tidak langsung dapat meminimalkan terjadinya fraud dan fraud yang dapat merugikan bank. Kegiatan pengendalian bank mencakup otorisasi yang tepat atas transaksi kredit dan pemisahan fungsi. Pemisahan fungsi harus dilakukan untuk mengurangi peluang seseorang melakukan kecurangan atau perbuatan tercela. Hal ini sejalan dengan teori keagenan dimana fungsi dipisahkan untuk menghindari konflik kepentingan. Dengan demikian, bank harus memastikan bahwa semua aktivitas transaksi tidak dikendalikan oleh satu pegawai. Hasil penelitian ini didukung oleh hasil penelitian Dewi \& Widhiyani (2018). Semakin baik kegiatan pengendalian yang dilakukan maka tingkat kredit bermasalah bank akan semakin menurun.

Hasil pengujian hipotesis keempat mengenai pengaruh informasi dan komunikasi terhadap kredit bermasalah menunjukkan nilai signifikansi sebesar 0,038 dengan koefisien regresi negatif sebesar 0,156. Nilai signifikansi 0,038 lebih kecil dari $=0,05$. Berdasarkan hasil pengujian, maka H4 diterima. Artinya terdapat pengaruh yang negatif dan signifikan antara informasi dan komunikasi terhadap kredit bermasalah pada Bank BRI di Denpasar. Artinya sistem informasi yang memadai akan menciptakan pengendalian internal yang baik. Informasi dan komunikasi yang ada di dalam bank memungkinkan pegawai untuk memahami perannya dalam sistem pengendalian internal. Hal ini juga dilakukan untuk menjaga komunikasi dan koordinasi antara atasan dan bawahan. Sejalan dengan teori keagenan dimana hubungan antara atasan dan bawahan harus dilakukan dengan baik agar tidak terjadi benturan kepentingan. Hasil penelitian ini didukung oleh penelitian Trisnadewi (2018) yang menyatakan bahwa informasi dan komunikasi berpengaruh negatif signifikan terhadap kredit bermasalah. Semakin baik informasi dan komunikasi yang tersedia, semakin rendah jumlah kredit bermasalah.

Hasil pengujian hipotesis kelima mengenai pemantauan kredit bermasalah menunjukkan nilai signifikansi sebesar 0,0440 dengan koefisien regresi negatif sebesar 0,237 . Nilai signifikansi 0,0440 lebih kecil dari $=0,05$. Berdasarkan hasil pengujian, maka H5 diterima. Artinya terdapat pengaruh negatif dan signifikan antara pemantauan kredit bermasalah pada Bank BRI di Denpasar. Artinya pengawasan yang baik akan menciptakan pengendalian internal yang baik pula. Kegiatan pemantauan meliputi proses evaluasi kualitas kinerja pengendalian internal dari waktu ke waktu, dan memastikan bahwa semuanya dilakukan sesuai dengan tujuan yang telah ditetapkan. Proses monitoring dilakukan secara terjadwal dan diambil tindakan yang tepat apabila kegiatan yang telah dilakukan tidak sesuai dengan kondisi yang terjadi (Dewi \& Widhiyani, 2018). Hal ini sejalan dengan teori keagenan dimana monitoring atau pengawasan selalu dilakukan untuk menghindari benturan kepentingan antara bank dengan debitur. Semakin baik pengawasan kredit yang dilakukan oleh bank maka kredit bermasalah akan semakin berkurang. Hasil penelitian ini didukung oleh hasil penelitian yang dilakukan oleh Dewi \& Widhiyani (2018) yang menemukan bahwa monitoring berpengaruh negatif signifikan terhadap kecenderungan kredit macet. Semakin baik pengawasan yang dilakukan pada bank maka kecenderungan kredit macet akan semakin berkurang.

Implikasi teoritis dalam penelitian ini mengggambarkan bahwa dukungan teori agensi (agency theory) dapat menjelaskan pengaruh penegndalian internal terhadap kredit bermasalah. Selain itu, hasil pengujian dapat memberikan kontribusi bagi pengembangan ilmu pengetahuan khususnya pada akuntansi keprilakuan, hal ini ditunjukkan karena akuntansi keprilakuan merupakan ilmu akuntansi yang berfokus tentang efek dari perilaku manusia sehingga dapat mempengaruhi data-data akuntansi dan juga pengambilan keputusan, jika dikaitkan dengan penelitian ini maka terkait dengan 
bagaimana perilaku manusia yang bekerja dalam suatu perusahaan melaksanakan tugasnya dalam proses pemberian kredit. Dengan adanya hasil penelitian pada akuntansi keprilakuan diharapkan dapat memberikan gambaran mengenai faktor yang dapat mempengaruhi kredit bermasalah, yang nantinya akan berdampak pada perilaku karyawab bank yang bertugas khususnya di bagian pemberian kredit.

Implikasi praktis dalam penelitian ini adalah hasil analisis pengaruh pengendalian internal terhadap kredit bermasalah, hasil dalam penelitian ini dapat memberi masukkan kepada manajemen yaitu menciptakan lingkungan kerja yang baik. Penelitian ini diharapkan dapat memberikan masukkan kepada karyawan bank agar memberikan informasi yang benar guna menciptakan pengendalian internal yang baik serta meningkatkan evaluasi terhadap kinerja dengan menekankan terhadap peraturan yang berlaku agar tidak terjadi penyimpangan-penyimpangan dalam pelaksanaan kegiatan dalam pencapaian tujuan organisasi

\section{SIMPULAN DAN SARAN}

Berdasarkan hasil pembahasan maka dapat disimpulkan bahwa lingkungan pengendalian berpengaruh negatif signifikan terhadap kredit bermasalah pada Bank BRI di Denpasar. Semakin baik lingkungan pengendalian yang dilakukan BRI maka akan mengurangi kredit bermasalah. Penilaian risiko berpengaruh negatif signifikan terhadap kredit bermasalah pada Bank BRI di Denpasar. Semakin baik penilaian risiko yang dilakukan BRI maka akan mengurangi kredit bermasalah. Aktivitas pengendalian berpengaruh negatif signifikan terhadap kredit bermasalah pada Bank BRI di Denpasar. Semakin baik aktivitas pengendalian yang dilakukan BRI maka akan mengurangi kredit bermasalah. Informasi dan komunikasi berpengaruh negatif signifikan terhadap kredit bermasalah pada Bank BRI di Denpasar. Semakin baik informasi dan komunikasi yang dilakukan BRI, akan mengurangi kredit bermasalah. Monitoring berpengaruh negatif signifikan terhadap kredit bermasalah pada Bank BRI di Denpasar. Semakin baik pemantauan yang dilakukan oleh BRI maka akan mengurangi kredit bermasalah.

Berdasarkan hasil penelitian dan simpulan diatas, maka dapat diajukan saran bagi perusahaan diharapkan memiliki upaya untuk mencegah terjadinya risiko internal perusahaan, hal ini dilakukan untuk menghindari kesalahan yang berdampak pada bank. Bagi peneliti selanjutnya diharapkan peneliti selanjutnya tidak hanya mengandalkan faktor-faktor dalam penelitian ini yaitu pengendalian internal saja tetapi dapat menambahkan faktor-faktor lain yang dapat mempengaruhi kredit bermasalah, dan dapat menambah atau menggunakan subjek penelitian lainnya.

\section{REFERENSI}

Afkar, T. (2018). “Analisis Pengaruh Non Performing Financing Dengan Kontrak Pembiayaan Bagi Hasil Terhadap Profitabilitas Bank Umum Syariah Di Indonesia”. AKRUAL : Jurnal Akuntansi, 10(1), 1-10

Anthony dan Govindarajan.2005. "Sistem Pengendalian Manajemen”, Edisi 11, Penerjemah: FX. Kurniawan Tjakrawala, dan Krista. Salemba Empat, Jakarta

Ari, K., \& Wilatini, D. (2019). "Pengaruh Pengendalian Internal Pada Efisiensi Kredit Di Lembaga Perkreditan Desa (LPD) Se-Kecamatan Sukawati Kabupaten Gianyar”. E-Jurnal Akuntansi, 1(2), 874-902

Aryasa, IPGCA, \& Wasistha, GH (2018). "Sistem Pengendalian Internal Untuk Non Performing Loan Pada Lembaga Perkreditan Desa (LPD) X". Soedirman Accounting Review, 03, 141-159.

Dewi, IGAL, \& Widhiyani, NLS (2018). "Pengaruh Unsur-Unsur Struktur Pengendalian Intern pada Non Performing Loan di Lembaga Perkreditan Desa Kota Denpasar”. E-Jurnal Akuntansi Universitas Udayana, 25, 406-433

Ekinchi, A. (2016). "Pengaruh Risiko Kredit dan Pasar pada Kinerja Bank: Bukti dari Turki. Jurnal Internasional Pengaruh Struktur Pengendalian Internal Terhadap Kredit Bermasalah pada Bank BRI di Denpasar, Ni Putu Via Rista dan Ni Luh Sari Widhiyani 
Ekonomi dan Masalah Keuangan”, 6(2), 427-434

Ghazwani, Ines. (2016). "Faktor Penjelasan Risiko Kredit: Bukti Empiris Dari Bank Tunisia". Jurnal atau Ekonomi, Keuangan, dan Manajemen.5(1). 1-20

Halim, Abdul. (2008). “Auditing 1 (Dasar-Dasar-Dasar Audit Laporan Keuangan)”. Edisi Kedua. Semarang: Universitas Diponogoro

Hasbiana \& Aditya. (2021). "Pengaruh Pengendalian Internal dan Kepatuhan Terhadap Aturan Akuntansi Terhadap Kualitas Laporan Keuangan Pada PT. Bank Sumut Medan”. Institut Penelitian dan Kritik Internasional Budapest-Journal. 4(1).12-19

Hidayat, Ahmad. (2016). “Apakah Likuiditas dan Solvabilitas Mempengaruhi Profitabilitas Bank? Bukti dari Bank Tercatat di Yordania". International Journal of Academic Research in Accounting, Finance and Management Sciences, 6 (1), 35-40

I Gede Sukadanayasa, \& Suardikha, IMS (2016). "Pengaruh Komponen Pengendalian Intern Terhadap Keputusan Pemberian Kredit Pada Bank Perkreditan Rakyat Di Kabupaten Tabanan”. E-Jurnal Akuntansi Universitas Udayana, 16, 1912-1937

Karuniawati, R. (2017). "Pengaruh Non Performing Loan Dan Loan To Deposit Ratio Terhadap Return On Asset”. Akademika, 15(1), 32-39.

Pratama, EH (2017). "Pengaruh Pengendalian Internal Terhadap Kredit Macet Perusahaan Perbankan (Studi Empiris pada Bank Konvensional BUMN di Bandar Lampung)".

Rotti, MR, Manossoh, H., \& Kalalo, MYB (2017). "Evaluasi Pengendalian Internal Terhadap Kredit Diragukan Pada Pt. Bank Sulutgo Di Minahasa Induk". Kelangsungan Hidup : Jurnal Riset Akuntansi, 12(2), 818827.

Trisnadewi, AA Ayu Erna. (2018). "PengaruhPengendalian Intern Terhadap Efektivitas Penyaluran Kredit Pada Lembaga Perkreditan Desa (LPD) di Kecamatan Abiansemal Kabupaten Badung”. Jurnal Riset Akuntansi Fakultas Ekonomi Universitas Warmadewa. 9(2), 1-20. 